\title{
Microbiological Quality and Risk Factor of Contamination of Whey in Meknes (Morocco)
}

\author{
Bouymajane $A^{1}$, Rhazi Filali $F^{1 *}$, Aboulkacem $A^{2}$, Ed-Dra $A^{1}$ and Chaiba $A^{1}$ \\ ${ }^{1}$ Team of Microbiology and Health, Laboratory of Chemistry-Biology Applied to the Environment, Moulay Ismail University Faculty of Sciences, Morocco
}

${ }^{2}$ Regional laboratory of epidemiological diagnosis and environmental hygiene, Fes-Meknes, Morocco

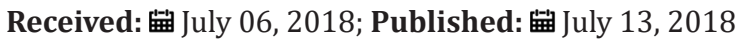

*Corresponding author: Rhazi Filali F, Team of Microbiology and Health, Laboratory of Chemistry-Biology Applied to the Environment, Moulay Ismail University Faculty of Sciences, BP. 11201 Zitoune Meknes, Morocco

\begin{abstract}
Lben is traditional fermented milk produced in rural and consumed throughout Morocco, without prior treatment. The main objective of this research is was to study the microbiological quality of lben marketed by street traders in Meknes city of Morocco. Lben samples were collected randomly between May 2015 and April 2016 from 3 street trader's sale point, two were located in popular neighborhoods (site 1) and one in popular market (site 2). The samples were analyzed for the presence and counts bacteria. Results indicated the maximum microbiological load with Total plate count ( $9.23 \log _{10}$ ufc.mL $\left.{ }^{-1}\right)$, Total coliforms ( $\left.7.20 \log 10 \mathrm{cfu} \cdot \mathrm{mL}^{1}\right)$, Lactic acid bacteria (8.93 $\left.\log 10 \mathrm{ufc} . \mathrm{mL}^{-1}\right)$, yeasts and molds ( $3.90 \log 10 \mathrm{ufc}$. $\left.\mathrm{mL}^{-1}\right)$. For pathogenic bacteria the percentages found in the total of lben samples analyzed are for Escherchia coli 27/36 (75.00\%), Staphylococcus aureus 27/36 (75.00\%), Clostridium perfringens 20/36 (55.55\%) and Listeria monocytogenes 7/36 (19.88\%). The examined samples did not contain Salmonella. For all stations, the highest bacterial counts in whey samples were recorded during the hot season $(\mathrm{P}<0.05)$. However, the sampling site has no significant effect on the quality of the product. These high levels of microbiological load and occurrence of bacteria pathogenic, reflect the poor hygienic quality of lben samples during the course of its preparation and its condition sale.
\end{abstract}

Keywords: Whey; Street Traders; Microbiological Quality; Season

\section{Introduction}

The Moroccan lben (Whey) is a refreshing cultured prepared by spontaneous fermentation of raw milk until coagulation, followed by a slight wetting, then a churn, allowing to collect a more or less fat in the form of raw butter called (Smen) (Benkerrouma 2004). Whey is a product rich in an aroma compounds such as, ethanol, acetoin, diacetyl and acetaldehyde, that play an important role in its organoleptic quality, also it's rich a moisture, poor a fat and crude proteins, compared to raw better, smen and jben. It spontaneously fermented at ambient temperature until goagulation. It has played a major role in the diet and communities in the rural region (Benkerrouma 2004). Whey is considered as a natural medium for spoilage and pathogen bacteria, lactic acid bacteria (LAB) contribute to an improvement of organoleptic, gastronomic and bio-conservative quality of food and as an alternative antibiotics by its natural substance such as, organic acids, fatty acids, sugars, hydrogen peroxide, vitamins, bacteriocins, alcohol, aromatic compounds and flavors (Lorey 2004). Also studies showed that LAB may be opportunistic and obligate pathogens responsible for human infections and diseases Carr et al. [1]. Other work reveled that Lactococcus Leuconoctoc, and Enteroccoci species were isolated in moroccan whey, with pathogenic microorganisms such as coliforms, Escherchia coli, group D streptococci, Staphylococcus aureus, Listeria monocytogenes, moulds and yeast (Benkerrouma 2004) [2-7].
Despite its poorly hygienic quality, Whey is being the most sold by street traders, who supply the traditional dairies in towns and cities. The consumption of dairy products remains relatively low, with nearly 45 liters per person per year, against 90 liters per person per year are recommended (Bertrand 2007). From 1998 to 2005, data in the USA indicate 39 outbreaks causing 831 cases with 66 hospitalizations and one death which were related to the consumption of raw milk. Others sources of illness were homemade ice cream, soft unripe Ned cheese made from raw milk, and rarely butter and milk powder. In Europe and the USA, milk and milk products are implicated in 2-6\% of all bacterial foodborne outbreaks (Motarjemi 2014). In 2015, the Anti-Poison and Pharmaco-vigilance Center (APPC) in Morocco, identified 2887 cases of foodborne illnesses, $60.8 \%$ of which were cases of collective poisoning. The analysis of the products subject to the Codex Alimentarius classification was: meat and meat products (21.7\%), dairy products $(9.2 \%)$ fish and fishery products $(8.7 \%)$ and composite foods (7.0\%) (APPC, 2015). It's should be mentioned that no studies have been done before on the microbiological quality of whey (lben) marketed by street traders in the city of Meknes. This area is characterized by intense agriculture including cattle breeding intended to milk production, the whey is directly consumed by Moroccan population and it is not subject to any prior control. For these reasons, the main objective of this work is to 
evaluate the microbiological quality of traditionally fermented milk, marketed by street vendors in the city of Meknes of Morocco, and to determine the infectious risks associated with its consumption [8-14].

\section{Materials and Methods \\ Sample collection}

Thirty six whey samples for microbiological evaluation were collected from 3 randomly selected street trading sale point, two popular neighborhoods (site 1 and site 2) and as well as a souk located in northern central Morocco in Meknes city. Samples were collected between May 2015 and April 2016. Each milk sample consisted $1 \mathrm{~L}$ of raw milk collected aseptically into a sterile container. Samples were brought to the Laboratory of microbiology and health of the Faculty of Science of Meknes city, in cool box and kept at $4^{\circ} \mathrm{C}$ until microbial analysis, which was performed in the same day $[15,16]$.

\section{Microbiological Analysis}

$25 \mathrm{~g}$ of each sample was homogenized in $225 \mathrm{~mL}$ of buffered peptone water (Oxoid, Beauvais, England), using a Masticator (Stomacher 400 Circulator, Seward) for $3 \mathrm{~min}$ at 260 rotations per minute (rpm) and serially diluted before plating. The samples were evaluated for total microbial count; they were counted after incubation on Plant Count Agar (Biokar, Beauvais, England) at $37^{\circ} \mathrm{C}$ for 48h (NF V08-051, 1999). Total and fecal coliform were carried out on Violet Red Bile Glucose agar (Biokar, Beauvais, England), after incubation during 24 hours (h) at $30^{\circ} \mathrm{C}$ (ISO 4832, 2006) and $42^{\circ} \mathrm{C}$ (NF V08-060, 2009) Respectively. Presumptive E. coli colonies were tested by the peptone water of indole test (V08-053,2002). Staphylococcuss pp. were counted on Baird Parker medium (Biokar, Beauvais, England) agar containing 5\% of the eggs yolk. After incubation for $48 \mathrm{~h}$ at $37^{\circ} \mathrm{C}$, the presumptive Staphylococcus aureus colonies were confirmed by the coagulase test (NF V08-057, 2004). Clostridium perfringens were determined on Tryptone Cycloserine Sulphite (Biokar, Beauvais, England) agar supplemented with D-cycloserine (Biokar, Beauvais, England) and incubated at $46^{\circ} \mathrm{C}$ for $24 \mathrm{~h}$ (NM 08.0.125. 2012.). Mould and yeasts were performed after incubation on Sabouraud dextrose agar with chloramphenicol (Biokar, Beauvais, England) at $25^{\circ} \mathrm{C}$ for 5 days (ISO 7954, 2003). Lactic acid bacteria (LAB) colonies grown on de Man, Rogosa and Sharpe (Biokar, Beauvais, England) agar at $30^{\circ} \mathrm{C}$ for $72 \mathrm{~h}$ (ISO/ FDIS 15214:1998). According to the norm (NF U47-100, 2007) for the detection of Salmonella spp., Kauffmann agar enrichment media (Oxoid, Beauvais, England), was used for an incubation of $48 \mathrm{~h}$ at $37^{\circ} \mathrm{C}$, a second incubation was performed with Rappaport media (Biokar, Beauvais, England), at $41^{\circ} \mathrm{C}$ for $24 \mathrm{~h}$, both incubation products were finally grown on Xylose-Lysine-Deoxycholate agar medium and Hektoen (Biokar, Beauvais, England) respectively, and incubated at $30^{\circ} \mathrm{C}$ for $48 \mathrm{~h}$. Listeria monocytogenes was detected according to (NM 08.0.110.2004). 10mL of lben samples were enriched on 90 $\mathrm{mL}$ half Fraser Broth (containing supplements ferric ammonium citrate 5\%) (Biokar, Beauvais, England), followed homogenized and incubated at $30^{\circ} \mathrm{C}$ for $24 \mathrm{~h}$, after $0.1 \mathrm{~mL}$ was transferring on to $0.9 \mathrm{~mL}$ Fraser Broth (containing supplements ferric ammonium citrate 5\%) (Biokar, Beauvais, England), for incubation at $37^{\circ} \mathrm{C}$ for $48 \mathrm{~h}$. After enrichment, $10 \mu \mathrm{L}$ volumes were streaked onto PALCAM (supplemented with PALCAM Selective Supplement), (Biokar, Beauvais, England), agar plates. Plates were incubated aerobically at $37^{\circ} \mathrm{C}$ for $24 \mathrm{~h}$. Presumptive Listeria monocytogenes were purified on Trypticase Soy Agar (Biokar, Beauvais, England), and confirmed using Gram staining, catalase, oxidase, heamolysis test, CAMP test, utilitzation of dextrose, esculin, maltose and galleries Api Listeria [17-23].

\section{Statistical Analysis}

All bacterial counts were expressed as $\log _{10}$ colony-forming units per milliliter $\left(\log _{10} \mathrm{cfu} . \mathrm{mL}^{-1}\right)$. The mean $\log _{10}(\mathrm{x})$ value were calculated on the assumption of a log normal distribution. The study of the effect of season and site of sampling was made by twoway ANOVA with repeated measures using software (SPSS, version 20 ). Differences were considered statistically significant at $\mathrm{p}<0.05$.

\section{Results and Discussion}

\section{Total Plate Count}

Total plate count are widely accepted measure of the general degree of microbial contamination and the hygienic conditions foods, in the current study, the results of TPC obtained for lben are from 5.73 to $9.23 \log _{10}$ ufc.mL $L^{-1}$ (Table 1 ). This value exceeds that limited by ministry of agriculture which is $5.47 \log _{10}$ ufc.mL ${ }^{1}$ (Ministre de l'agriculture, 2004). These results were higher than those found previously in the lben studied in the region RabatSalé in Morocco (9.10 $\mathrm{cfu}^{\mathrm{mL}} \mathrm{L}^{-1}$ ) (Hadrya 2012), those recorded in Ethiopia in fermented milk (4.47 $\log _{10}$ cfu.mL ${ }^{-1}$ ) (Zelalem and Bernard; 2006), (from $2.110^{8}$ to $6.110^{8} \mathrm{cfu}^{-\mathrm{mL}^{-1}}$ ) (Farhan and Salik,

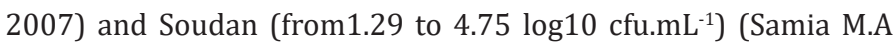
2009)

Table 1: Shows average counts $\left(\log _{10} \mathrm{cfu} \cdot \mathrm{mL}^{-1}\right)$ found in lben marketed by street traders in Meknes city of Morocco.

\begin{tabular}{|c|c|c|c|c|c|}
\hline & & $\begin{array}{l}\text { Total } \\
\text { plate } \\
\text { count }\end{array}$ & $\begin{array}{c}\text { Total } \\
\text { coliforms }\end{array}$ & $\begin{array}{c}\text { Lactic } \\
\text { acid } \\
\text { bacteria }\end{array}$ & $\begin{array}{c}\text { Yeasts } \\
\text { and } \\
\text { molds }\end{array}$ \\
\hline \multirow{3}{*}{ Autumn } & Site1 & 9.06 & 6.86 & 8.03 & 3.73 \\
\hline & $\begin{array}{c}\text { Popular } \\
\text { market }\end{array}$ & 9.23 & 7.2 & 8.56 & 3.9 \\
\hline & Site2 & 9.06 & 6.66 & 8.06 & 3.7 \\
\hline \multirow{3}{*}{ Winter } & Site1 & 6 & 4.9 & 5.91 & 2.2 \\
\hline & $\begin{array}{c}\text { Popular } \\
\text { market }\end{array}$ & 6.46 & 3.43 & 6.46 & 2.5 \\
\hline & Site2 & 5.43 & 4.2 & 5.43 & 1.86 \\
\hline \multirow{3}{*}{ Spring } & Site1 & 5.83 & 3.53 & 5.83 & 0.31 \\
\hline & $\begin{array}{c}\text { Popular } \\
\text { market }\end{array}$ & 6.13 & 3.8 & 5.9 & 2.13 \\
\hline & Site2 & 5.73 & 3.4 & 5.73 & 1.9 \\
\hline \multirow{3}{*}{ Summer } & Site1 & 8.86 & 6.13 & 8.83 & 1.03 \\
\hline & $\begin{array}{c}\text { Popular } \\
\text { market }\end{array}$ & 8.93 & 6.2 & 8.93 & 3.91 \\
\hline & Site2 & 8.86 & 3.96 & 8.83 & 3.7 \\
\hline
\end{tabular}

\section{Coliforms}

Colifroms belonging to the enterobacteriaceae family that is widespread in the digestive tract animals. The coliforms are often 
used as indicator of the sanitary conditions in the production and handling of the milk, starting from the production site to the consumer and also storage containers, and poor waste disposal methods by the dairy farms. E. coli and coliform bacteria are often used as indicator microorganisms of contamination. In our study, the results of total coliforms from 3.40 to $7.20 \log _{10}$ cfu.mL ${ }^{-1}$ (Table 1) were higher than that limited by Moroccan standard ( $3 \log _{10}$ cfu. $\mathrm{mL}^{-1}$ ) (Ministre de l'agriculture 2004) and that those found in Ethiopia (6.57 $\log _{10}$ cfu.mL $L^{-1}$ ) (Zelalem and Bernand, 2006), Sudan (5.61 cfu.mL $\mathrm{L}^{-1}$ ) and previously in Morocco (2 107 cfu.mL ${ }^{-1}$ ) (Hadrya 2012).

\section{Escherichia Coli}

Escherichia coli is normally a commensal bacterium that coexists with its human host in the intestines in a mutually beneficial relationship (Tchaptchet and Hansen,2011), It is a group of bacteria that are most used as indicator organisms for faecal contamination and breaches in hygiene. However, several E.coli clones have acquired virulence factors in some cases to cause serious disease. Among the pathogenic E.coli of greatest relevance to milk is E.coli 0157:H7 (Farrokh 2012). In this study, the prevalence of E.coli is $75 \%$ (Table 2). In Morocco, this value is lower than that found in traditional whey $(89.6 \%)$ and higher than that found in industrial whey (Hadrya 2014).

Table 2: Microbial load of lben from street traders in Meknes city of Morocco expressed by number of positive samples andin \%.

\begin{tabular}{|c|c|c|c|c|c|}
\hline & E. coli & S.aureus & $\begin{array}{c}\text { Clostridium } \\
\text { perfringens }\end{array}$ & Salmonella & $\begin{array}{c}\text { Liste- } \\
\text { ria } \\
\text { mono- } \\
\text { cytoge- } \\
\text { nes }\end{array}$ \\
\hline Autun & $9(25.00)$ & $7(19.44)$ & $5(13.88)$ & $0(0)$ & $0(0)$ \\
\hline Winter & $2(5.55)$ & $6(16.66)$ & $0(0)$ & $0(0)$ & $\begin{array}{c}4 \\
(11.11)\end{array}$ \\
\hline Spring & $6(16.66)$ & $5(13.88)$ & $6(16.66)$ & $0(0)$ & $3(8.33)$ \\
\hline Summr & $9(25.00)$ & $9(25.00)$ & $9(25.00)$ & $0(0)$ & $0(0)$ \\
\hline Total & $27(75.00)$ & $\begin{array}{c}27 \\
(75.00)\end{array}$ & $20(55.55)$ & $0(0)$ & $\begin{array}{c}7 \\
(19.44)\end{array}$ \\
\hline
\end{tabular}

\section{Yeasts and Molds}

Yeasts are an important part of the microflora of naturally fermented milk. Yeasts, whose presence in milk and dairy products are crucial for the desirable properties of carbone dioxide and ethanol (Narvhus and Gadaga, 2003). In our study, the yeasts and moulds counts ranged from $0.31 \log _{10}$ ufc.mL $L^{-1}$ to $3.90 \log _{10}$ cfu.mL $L^{-1}$ (Table 1).This value is less than that found in traditional fermented milk in Zimbabwe (from 2 to $8.08 \log _{10}$ cfu. $\mathrm{mL}^{-1}$ ) (Gadaga 2000), Belgium (from 3 to $5.65 \mathrm{cfu}^{\mathrm{mL}} \mathrm{L}^{-1}$ ) (Loreta 1998) and Ethiopia ( 5.8cfu.mL ${ }^{-1}$ ) (Fakadu 1994) .

\section{The Lactic Acid Bacteria}

The Lactic acid bacteria (LAB) are reported to play a major fermentative role affecting aroma, texture and acidity of the product, as well as being of some benefit to human health Clemencia et al. [24]. The microbiological load of LAB was $\left(5.43 \log _{10}\right.$ ufc. $\mathrm{mL}^{-1}$ to $8.93 \log _{10}$ ufc. $\mathrm{mL}^{-1}$ ) (Table 1 ). This value is higher than that found in Ethiopia (5.88 $\log _{10}$ ufc. $\mathrm{mL}^{-1}$ ) (Biratu and seifu, 2016), Sudan (6.83 $\log _{10}$ ufc. $\mathrm{mL}^{-1}$ ) Hassan et al. [25] and China (from 6.8 $\log _{10}$ ufc. $\mathrm{mL}^{-1}$ to $7.3 \log _{10}$ ufc. $\mathrm{mL}^{-1}$ ) Rahman et al. [26]. In Morocco previous studies show that percentage in Lactobacteria was a bout, 34\% Lactobacillu, 27\% Lactococcus, 22\% Leuconostoc 10\% Enterococcus were found in lben Ouadghiri et al. [27], 37.5\% and $25.8 \%$ of Lactobacillus and Lactococcus were found respectively in camel milk Khedid et al. [28] 34\% Lactobacillu, 27\% Lactococcus, 27\% Leuconostoc, 10\% Enterococcus and 1\% Streptococcus were detected in jben Ouadghiri et al. [29].

\section{Staphylococcus Aureus}

Staphylococcus aureus is a Gram-positive, which often occur in the udder of a cow with mastitis, some strains are capable of producing a highly heat stable protein toxin causes illness in humans Moselio [30]. In this study, the prevalence of Staphylococcus aureus is $75 \%$ (Table 2). Other study in Morocco showed that the S. aureus was also isolated from traditional lben with the value of $18.2 \%$ and 0\% from industrial lben (Hdrya 2012).

\section{Listeria monocytogenes}

Listeria monocytogenes is a Gram-positive bacterium responsible a foodborne pathogen of global concern, which poses significant health problem to both human and domestic animals Alhogail et al. [31]; Allen et al. [32]. Listeria monocytogenes is ubiquitous in nature and easily contaminates vegetables, fruits, dairy products, meat and seafood Jorgensen and Huss [33]; Moretro and Langsrud [34]. The mortality rate of Listeria monocytogenes is about 20$40 \%$ Alhogail et al. [35]. In this study, the prevalence of Listeria monocytogenes is $19.44 \%$ (Table 1), Others studies in Morocco, indicated the lowest prevalence in milk and dairy products, such as in raw milk $(0.8 \%)$ Hadrya et al. [36,37], raw milk and traditional dairy products (5.9\%) (El Marnissi et al., 2013) and raw milk and traditional whey $(0.7 \%)$ Amajoud et al. [38]. In Algeria, 5.8\% of Listeria monocytognes were found in raw milk (Boundir 2011). Several studies indicate that Listeria monocytogenes is responsible for human listeriosis that can manifest as septicemia, meningoencephalitis, neonatal infection with a high case fatality rate (20$30 \%$ ) Xin-jun et al. [39]. In Morocco we must point out that lben is a product, consumed without heat treatment and the lack of surveillance for Listeria monocytogenes, can causes a serious socioeconomic damage.

\section{Clostridium Perfringens}

Clostridium perfringens is a food poisoning sulphite reducing clostridia that can be found in raw milk (McAuly 2014). Clostridium perfringens food poisoning is caused by enterotoxin, which brings about severe abdominal cramps and diarrhea. Clostridium perfringens have also been identified as the etiological agents of bovine mastitis Ribeiro et al. [40]; Osman et al. [41]. In the current study, the prevalence of Clostridium perfringens is 55\% (Table 2), this value is higher than that reported by MaCauly et al in raw milk (33\%) (MaCauly 2014). In Egypt, The prevalence of Clostridium perfringens was 0, 20, 20 in sterilized milk, raw milk, milk powder, respectively (Rowauda 2015). 


\section{Factors Influencing the Risks of Contamination}

Analysis of variance showed that the seasonal factor had a highly significant effect on lben flora. The highest bacterial counts were recorded during the hot season $(\mathrm{P}<0.05)$. Microbial counts in autumn and summer samples were significantly higher $(\mathrm{p}<$ 0.05 ) than those of winter and spring (Table 3). It is explained by higher ambient temperatures, a lack of application of hygiene procedures by ignorance or negligence of their solicitation, and lack of refrigeration during storage and transportation. Prevalence of Escherichia coli, Staphylococcus aureus and Clostridium perfringens are also high among hot seasons. On the other hand, Listeria monocytogenes contamination is high during the cold season because this bacterium may grow over a wide range of $\mathrm{pH}$ (4.39.4) and even at refrigeration temperatures Garrido et al. [42] but Salmonella is not detected in these samples studied probably there is relation of activity of Lactic Bacteria and their presence Casey et al. [43-46].

Table 3: Effect of season and station on microbiological quality of whey marketed by street traders in Meknes city, statistically $\mathrm{P}<0.05$.

\begin{tabular}{|c|c|c|c|c|}
\hline & F & Critical F & P value \\
\hline \multirow{4}{*}{$\begin{array}{c}\text { Total plate } \\
\text { count }\end{array}$} & Site & 0.57 & 3.4 & 0.57 \\
\cline { 2 - 5 } & Season & 30.46 & 3 & $2.310^{-8}$ \\
\cline { 2 - 5 } & $\begin{array}{c}\text { Site } \times \\
\text { Season }\end{array}$ & 0.15 & 2.5 & 1 \\
\hline \multirow{4}{*}{ Total faecal } & Site & 0.95 & 3.4 & 0.4 \\
\cline { 2 - 5 } & Season & 16.8 & 3 & $4.2710^{-6}$ \\
\cline { 2 - 5 } & $\begin{array}{c}\text { Site } \times \\
\text { Season }\end{array}$ & 0.13 & 2.5 & 1 \\
\hline \multirow{4}{*}{$\begin{array}{c}\text { Lactic acid } \\
\text { bacteria }\end{array}$} & Site & 0.72 & 3.4 & 0.5 \\
\cline { 2 - 5 } & Season & 33.3 & 3 & $1.0110^{-8}$ \\
\cline { 2 - 5 } & $\begin{array}{c}\text { Site } \times \\
\text { Season }\end{array}$ & 0.16 & 2.5 & 1 \\
\hline \multirow{3}{*}{$\begin{array}{c}\text { Yeasts and } \\
\text { molds }\end{array}$} & Site & 0.86 & 3.4 & 0.43 \\
\cline { 2 - 5 } & Season & 24.1 & 3 & $2.0210^{-7}$ \\
\cline { 2 - 5 } & $\begin{array}{c}\text { Site } \times \\
\text { Season }\end{array}$ & 0.1 & 1 & 2.51 \\
\hline
\end{tabular}

\section{Conclusion}

Results of this study clearly indicated that microbiological quality of lben marketed by street traders to Moroccan consumers is poor. The highest bacterial counts in whey samples were recorded during the hot season. The presence of bacteria responsible for foodborne diseases can be considered as an alert on consumption of this product. In order to prevent lben contamination, some of measures are to be applied such as a broad microbiological assessment, the establishment of milk hygiene standard, information to the producers street traders and consumers about the potential health from milk [47-54].

\section{References}

1. Carr FJ, Chill D, Maida N (2002) The lactic acid bacteria: a literature survey. Critical Reviews in Microbiology 28(4): 281-370.
2. Samia MAA, Said Ahmad AMM, Ibtisam EMZ, EL Owni OAO, Ahmed MKA (2009) Microbiological and Physiochemical Properties of Raw Milk Used for Processing Pasteurized Milk in Blue Nile Dairy Company (Sudan). Aust J Basic and Applied Sci 3: 3433-3437.

3. Sintayehu Y, Haile W (2015) Assessment of Microbial quality and safety of a traditional fermented milk-'Irgo', collected from Hawassacity, South Ethiopia. Journal of Food Processing and Technology, p. 6-3

4. Tantaoui-Elaraki A, El Marrakchi A (1987) Study of the Moroccan dairy products: Lben and smen, Mircen Journal 3(3): 211-220.

5. Tantaoui Elaraki A, Berrada M, El Marrachi A, Berramou A (1983) Etude sur le leben marocain. Le Lait 63(627-628): 230-245.

6. Tchaptchet S, Hansen J (2011) The Yin and Yang of host-commensal mutualism. Gut Microbes 2(6): 347-352.

7. Zelalem Y, Bernard F (2006) Handling and Microbial load of Cow's milk and Irgo-Fermented milk collected from different shops and producers in the central highlands of Ethiopia. Ethiopian Journal of Animal Production 6: 67-82.

8. (2004) Norme Francaise V08-057. Microbiology of food and animal feeding stuffs. Enumeration of coagulase-positive staphylococci by colony- count technique at $37^{\circ} \mathrm{C}$-Technical settlements without confirmation, p. 1-10.

9. (2009) Norme Française V08-060. Microbiology of food and animal feeding stuffs. Enumeration of thermotolerant coliforms by colonycount technique at $44^{\circ} \mathrm{C}$, p. 1-10.

10. (2004) Norme Marocaine NM 08.0.110. Microbiologie alimentaire. Recherche de Listeria monocytogenes.

11. (2003) Norme Marocaine NM ISO 7954. Directrice générale pour le dénombrement des levures et moisissures. techniques par comptage des colonies à $25^{\circ} \mathrm{C}$.

12. (2012) Norme Marocaine NM 08.0.125. Dénombrement en anérobiose des bactéries sulfite-réductrices par comptage des colonies à $46^{\circ} \mathrm{C}$.

13. (2015) Poison Control and Pharmacovigilance Center (PCPC). Review of toxicology, Morocco.

14. Rowayda O, Marwa K, Al-Toukhy, Maha Al-Ashmawy M (2015) Prevalence and Antimicrobial Resistance of Clostridium perfringens in Milk and Dairy Products. World Journal of Dairy \& Food Sciences 10: 141-146.

15. (2007) Norme Française U47-100. Methods of animal health analysis. Search by isolation and identification of any serotype or serovar(s) specified(s) of Salmonella in the environment of livestock production, p. 1-10.

16. (2002) Norme Française V08-053. Microbiology of food and animal feeding stuffs. Horizontal method for the enumeration of betaglucuronidase positive Escherichia coli by counting the colonies at $44^{\circ} \mathrm{C}$ using 5-bromo-4-chloro-3-indolyl $\beta$-D-glucuronide, p. 1-10.

17. Jakobsen M, Narvhus J, Viljoen BC (1998) Yeasts in the dairy industry: Positive and negative aspects, Proceedings of the symposium. Interantional Dairy Federation, p.178-182.

18. Leroy, F, De V (2004) Lactic acid bacteria as functional starter cultures for the food fermentation industry. Trends in Food Science \& Technology 15: 67-78.

19. Loretan T, Viljoen BC, Mostert JF, Vogel AM, Jordaan HF (1998) A preliminary study of the diversity and techno-logical properties of indigenous traditional South African fermented milk.

20. Mc Auley CM, Mc Millan K, Moore SC, Fegan N, Fox EM (2004) Prevalence and characterization of foodborne pathogens from Australian dairy farm environments. Journal of Dairy Sciences 97(12): 7402-7412.

21. Motarjemi Y, Moy GG, Jooste PJ, Anelich LE (2014) Milk and Dairy Products. Food safety Management, p. 83-117. 
22. Mutukumira AN (1995) Properties of amasi, a natural fermented milk produced by smallholder milk producers in Zimbabwe. Milchwissenschaft 50: 201-205.

23. Narvhus JA, Gadaga TH (2003) The role of interaction between yeasts and lactic acid bacteria in African fermented milks: a review. International Journal of Food Microbiology 86(1-2): 51-60.

24. Clemencia CL, Annalisa S, Maria M, Antonello P, Esteban OC, et al. (2011) Microbiological characteristics of kumis, a traditional fermented Colombian milk, with particular emphasis on enterococci population. Food Microbiology 28(5): 1041-1047.

25. Hassan RA, El Zubeir IEM, Babiker SA (2008) Chemical and microbial measurements of fermented camel milk "Gariss" from transhumance and nomadic herds in Sudan. Australian Journal of Basic and Applied Sciences 2: 800-804.

26. Rahman N, Xiaohong C, Meiqin F, Mingsheng D (2009) Characterization of the dominant microflora in naturally fermented camel milk shubat. World Journal of Microbiology and Biotechnology 25(11): 1941-1946.

27. Ouadghiri M (2009) Biodiversité des bactéries lactiques dans le lait cru et ses dérives "Lben" et "Jben" d'origine marocaine. Thèse, Université Mohammed V Agdal, Rabat, Maroc.

28. Khedid K, Faid M, Mokhtari A, Soulaymani A, Zinedined A (2006) Characterization of lactic acid bacteria isolated from the one humped camel milk produced in Morocco. Microbiological Research 164(1): 8191.

29. Ouadghiri M, Amar M, Vancanneyt M, Swings J (2005) Biodiversity of lactic acid bacteria in Moroccan soft white cheese (Jben). FEMS Microbiology Letters 251(2): 267-271.

30. Moselio S (2009) Encyclopedia of microbiology. Elsevierinc, USA, p. 3444.

31. Alhogail S, Suaifan GARY, Zourob M (2016) Rapid colorimetric sensing platform for the detection of Listeria monocytogenes foodborne pathogen. Biosens Bioelectron 86: 1061-1066.

32. Allen KJ, Wałecka Zacharska E, Chen JC, Katarzyna K, Devlieghere F, et al. (2016) Listeria monocytogenesan examination of food chain factors potentially contributing to antimicrobial resistance. Food Microbiology 54: $178-189$.

33. Jorgensen LV, Huss HH (1998) Prevalence and growth of Listeria monocytogenes in naturally contaminated seafood. International Journal of Food Microbiology 42(1-2): 127-131.

34. Moretro T, Langsrud S (2004) Listeria monocytogenes: biofilm formation and persistence in food-processing environments. Biofilms 1(2): 107121.

35. Hadrya F, El ouardi A, Hami H, Soulaymani A, Snouci S (2012) Évaluation de la qualité microbiologique des produits laitiers commercialisés dans la région de Rabat-Salé-Zemmour-Zaer au Maroc Microbiological quality assessment of dairy products marketed in Rabat-Salé-ZemmourZaerregion in Morocco, Cahiers de nutrition et de diététique 47(6): 303307.

36. Hadrya F, Elouardi A, Benali D, Hami H, Soulaymani A, et al. (2012) Bacterial quality of informally Marketed raw milk in Kenitra city, Morocco. Pakistan Journal of Nutrition 11(8): 662-669.

37. Amajouda N, Alexandre LJ, Sorianoc JM, Bracq Dieyeb H, El Maadoudid, et al. (2018) Prevalence of Listeria spp. and characterization of Listeria monocytogenesi solated 2 from food products in Tetouan, Morocco. Food Control 84: 436-441.

38. Ribeiro M, Lara G, Bicudo S, Souza A, Salerno T, et al. (2007) An unusual gangrenous goat mastitis caused by Staphylococcus aureus, Clostridium perfringens and Escherichia coli co-infection, Arquivo Brasileiro de Medicina Veterinária e Zootecnia 59(3): 810-812.
39. Xin jun D, Xiang Z, Xiao yi W, Yu lan S, Ping Li, et al. (2017) Isolation and characterization of Listeria monocytogenes in Chinese food obtained from the central area of China. Food Control 74: 9-16.

40. Osman K, El-Enbaawy M, Ezzeldeen N, Hussein H (2009) Mastitis in dairy buffalo and cattle in Egypt due to Clostridium perfringens: prevalence, incidence, risk factors and costs, Revue Sciences et Technique 28(3): 975-986.

41. Garrido A, Chapela MJ, Roman B, Ferreira M, Lago J, et al. (2012) Development of a multiplex real-time PCR method for simultaneous detection of Salmonella enterica, Shigella flexneri and Listeria monocytogenes in processed food samples, Eur. Food Res. Technol 234(4): 571-580

42. Casey PG, Casey GD, Gardiner GE, Tangney M, Stanton C, et al. (2004) Isolation and characterization of anti-Salmonella lactic acid bacteria from the porcine gastrointestinal tract. Letters in Applied Microbiology 39(5): 431-438.

43. Arrêté conjoint du ministre de l'agriculture et du développement rural, du ministre de la santé et du ministre de l'industrie, du commerce et des télécommunications $n^{\circ} 624-04$ du 17 safar 1425 (8 avril 2004) relatif aux normes microbiologiques auxquelles doivent répondre les denrées animales ou d'origine animale. 2004.

44. Benkerroum N, Tamime AY (2004) Technology transfer of some Moroccan traditional dairy products (lben, jben and smen) to small industrial scale. Food Microbiology 22(4): 399-413.

45. Bertrand H (2007) International center for advanced Mediterranean agronomic studies (CIHEAM). ( $1^{\text {st }}$ edn.), Mediterra Publsher, Paris, p. 279-297.

46. Biratu K, Seifu E (2016) Chemical composition and microbiological quality of Dhanaan: Traditional fermented camel milk produced in eastern Ethiopia. International Food Research Journal 23(5): 22232228.

47. Boubendir A, Mostakim HM, El Abed S, Koraichi IS (2011) Incidence de 294 Listeria spp. et autres bactéries psychrotrophes dans le lait cru bovin dans le Nord 295 Est Algérien. Revue de Médecine Vétérinaire162(5): 265-269.

48. Boujemaa EM, Bennani L, Cohen N, El Ouali Lalami A, Belkhou R (2013) Presence of Listeria monocytogenes in raw milk and traditional dairy products marketed in the north-central region of Morocco. African Journal of Food Science 7(5): 87-91.

49. Choreh F, Kieran J, Frederic A, Kathleen G, Hanne Od, et al. (2012) Review of Shiga-toxin-producing Escherichia coli (STEC) and their significance in dairy production. International Journal of Food Microbiology 162(2): 190-212.

50. Farhan M, Salik S (2007) Evaluation of bacteriological contamination in raw (unprocessed) milk sold in different regions of Lahore. Journal of agriculture and social sciences 3: 104-106.

51. Fekadu B (1994) Present situation and future aspects of milk production, milk handling and processing of dairy products in Southern Ethiopia. Thesis, Agricultural University of Norway.

52. Gadaga TH, Mutukumira AN, Narvhus JA (2000) Enumeration and identication of yeasts isolated from Zimbabwean traditional fermented milk. International Dairy Journal 10(7): 459-466.

53. ISO 4832 (2006) Microbiology of food and animal feeding stuffshorizontal method for the enumeration of coliforms -colony-count technique, p. 6 .

54.ISO/FDIS 15214 (1998) Microbiology of food and animals feeding stuffs-horizontal method for the enumeration of mesophilic lactic acid bacteria, p. 1-8. 


\section{ISSN: 2574-1241}

DOI: $10.26717 / B J S T R .2018 .06 .001410$

Rhazi Filali F. Biomed J Sci \& Tech Res

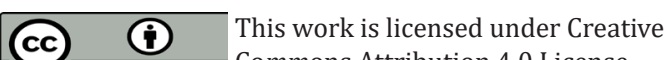

Submission Link: https://biomedres.us/submit-manuscript.php

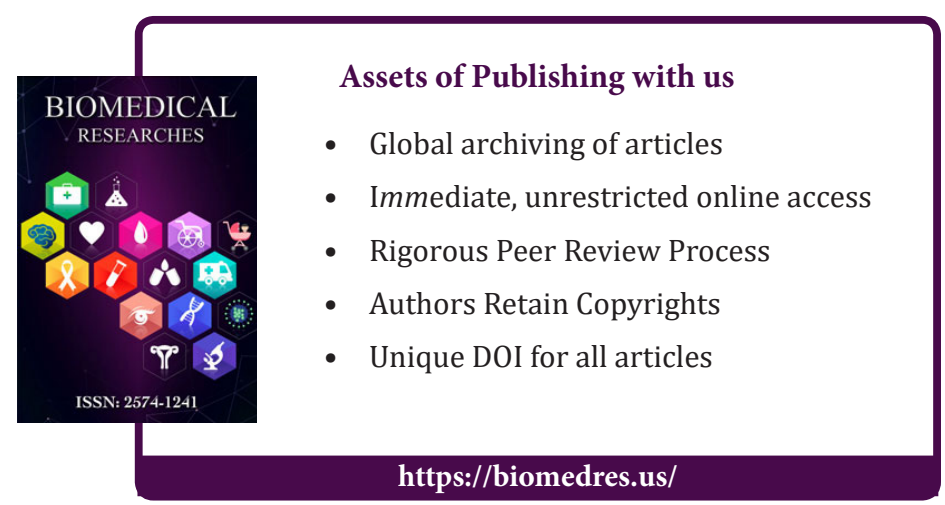

